\title{
A pathogen-specific approach towards udder health management in dairy herds: Using culture and somatic cell counts from routine herd investigations
}



A dedicated udder health diagnostic programme was developed and used over a 15-year period in South Africa to analyse milk samples based on microbiological and cytological patterns within various groups and for individual cows and udder quarters in dairy herds. These pathogen-specific analyses are utilised for pro-active improvement and management of udder health in South African commercial dairy herds. The programme acts as a monitoring tool and identifies management areas at risk and individual cows with udder disease and uses both quarter and composite milk samples. Intra-mammary infection (IMI) is a dynamic situation and depending on the time a milk sample is taken, false-negative results may be obtained. A new IMI and an infection that is curing may both have low somatic cell counts (SCCs), masking the true bacterial status. SCC in individual infected udder quarters may differ greatly depending on the causative bacterial species, its pathogenicity, the host immune status and the environmental factors involved. A pathogen-specific udder health approach was followed with repeated herd tests to take account of these udder health dynamics. The results of the herd IMI investigation are applied in practice to assist veterinarians, udder health consultants and managers to make informed and specific detailed decisions at both a herd and on an individual cow basis regarding udder health.

\section{Introduction}

Mastitis is an endemic disease and is considered the most frequent and costly disease in the dairy industry responsible for the highest financial losses, which affects both the animal and the quality of the product (Halasa et al. 2007; Hogeveen et al. 2010).

Mastitis is complex and multifactorial in nature and generally results from an interaction between a variety of microbial infections, host factors and environmental and management factors and with generally poor treatment success. It is defined by the National Mastitis Council (NMC) as an inflammation of the mammary gland mainly caused by bacterial infection (NMC Guidelines 2001). Dealing with clinical mastitis cases remains important but damage to the udder parenchyma may lower a cow's lifetime production potential and increases the risk of infecting fellow cows by the shedding of pathogens (DeGraves \& Fetrow 1993; White 2010). Optimal management practices are considered to be the most effective way to control the disease. Work done during the 1960s set the stage for our current understanding of mastitis and established standards for contagious mastitis control (Davidson 1961; Dodd et al. 1969; Neave, Dodd \& Kingwill 1966; Neave et al. 1969). From this work, a five-point mastitis control programme was developed and was later upgraded to the NMC 10-point mastitis control plan (Smith \& Hogan 2001). Utilisation of this programme has led to a reduction in the prevalence and elimination of contagious mastitis from many South African farms. However, Staphylococcus aureus and Streptococcus agalactiae remain a challenge in individual farms in South Africa and abroad (Petzer et al. 2009).

In a paper published by Middleton (2013), he questioned what we have learned regarding S. aureus mastitis in the last 50 years. His answer summarised the global udder health dilemma. We have gained much knowledge but the basic fact that milking time hygiene is the main critical control point has not changed. Decisions regarding the control of mastitis in a given herd will depend on the contagiousness, persistence and inflammatory nature of the main infecting species and strains. The use of historical data to evaluate true new intra-mammary infection (IMI) rates, the extent of chronic carriers within the herd and the bacterial cure rates in combination with somatic cell count (SCC) levels are all valuable measures to identify mastitis and stress-related causes of high SCC. 
Knowledge of the bacterial species present in the udders of cows in a herd and the ability to identify cows with and without IMI can be used as a tool for in-depth management decisions. In order to control the transmission rate of contagious pathogens by limiting new IMI, cows infected with contagious udder pathogens can be milked last, thereby limiting the risk of spreading this infection to the healthy cows. Parlour supervision of the cows infected with contagious pathogens should then be intensified. It has been well established that the probability of IMI cure depends on the cow, pathogen and treatment factors (Barkema, Schukken \& Zadoks 2006). Although treatment success is influenced by choice and use of an appropriate product and also the lactation stage of the cow, the main factor influencing treatment success has been found to be treatment duration (Barkema et al. 2006). In addition to the bacterial species or strains involved, their pathogenicity and possible antimicrobial resistance need to be considered, as well as the immune response of the cow. Cure rates for S. aureus mastitis have been found to range from 3 to $74 \%$. Cure is lower in older cows, and in those with high SCC, it increased chronic IMI and increased the numbers of mammary quarters infected(Barkemaetal.2006).Spontaneouscure of new S.aureus IMI may be as high as $21 \%$, while in chronic cases, this figure can be as low as 3\% (Swinkels, Schukken \& Cox 2012). Only a few udder pathogens such as S. agalactiae are known for a high treatment success during lactation (Keefe 1997). Staphylococcus aureus and S. agalactiae IMI are still present in dairy herds in South Africa (Petzer et al. 2013) and warrant a more efficient testing system to enable producers to eliminate both these pathogens from their herds.

The SCC measure has been used worldwide for several decades as a primary indicator of udder health in dairy herds (Heeschen 2010; Hillerton 1999; Reneau 2001). More than $95 \%$ of the cells in milk are leucocytes consisting of variable proportions of macrophages that recruit the neutrophils and lymphocytes in the event of invading pathogens by releasing chemo-attractants (Burvenich et al. 2000; Sharma, Singhand \& Bhadwa 2011; Zeconni \& Smith 2000). The lymphocytes act mostly as memory cells for the immune system while neutrophils phagocytise and destroy the pathogens. Less than $5 \%$ of SCC consists of epithelial cells originating from the mammary gland (Harmon 2001; Lee, Wooding \& Kemp 1980). The level of SCC in milk depends on various factors of which IMI is the most important. Factors include parity, stage of lactation, milking frequency, stress (environmental, nutritional, systemic disease and day-to-day changes in management) and non-specific disturbance (NSD) where an increase in SCC is not caused by pathogens (Laevens et al. 1997; Sandrucci et al. 2014; Wegner et al. 1976; Yagi et al. 2004).

Traditionally, bulk milk tank somatic cell count (BMSCC) is used as a primary index when analysing herd udder health and is used as one of the quality criteria for payment by the secondary milk industry (Ruegg \& Pantoja 2013). High BMSCC could indicate udder health problems, whereas a too low level (below 100000 cells/mL) should act as a warning that mastitis caused by coliform bacteria may increase (Shuster, Lee \& Kehrli 1996; Suriyasathaporn et al. 2000). However, the BMSCC provides only an estimation of the prevalence of infection and irritation of the udders of the cows. This is not a true reflection of the herd udder health status as milk from problem cows should have been excluded (cows with clinical mastitis, fresh in milk cows, cows under treatment and sometimes those with high SCC). The BMSCC can also be influenced by herd dynamics such as the average parity of cows, and the distribution of lactation stage seen in seasonality calving herds compared to herd with an all-yearround calving pattern (Laevens et al. 1997). The impact of any individual cow on BMSCC will further depend on its SCC and the milk yield of the cow and the dilution factor within the tank. It has been estimated that there is likely to be a $10 \%$ increase in IMI prevalence in a herd for every 100000 cells $/ \mathrm{mL}$ increase in BMSCC (Bradley 2007). In the year 2014, an estimated 145 million dairy farms operated globally and the largest average dairy herds were found in Saudi Arabia (8125 cows) followed by New Zealand (393 cows) and South Africa (238 cows) (Lactodata 2014). The larger the herd, the more critical the interpretation of the BMSCC needs to be and the less valuable it becomes as a pro-active udder health monitoring tool because of the dilution effect of the milk masking high SCC of an individual cow.

To evaluate changes in udder health status, the SCCs of individual cows are often analysed together with herd clinical mastitis statistics (Bradley \& Green 2001). An SCC threshold is used as a guideline to estimate new IMI, chronic IMI and cure rates and those cows or udder quarters that remain without IMI. There has never been absolute consensus regarding the correct threshold level to indicate IMI. Some consensus was reached regarding an SCC standard of $\geq 200000$ cells $/ \mathrm{mL}$ quarters milk as the indicator of IMI at two World Dairy Summits (Athens 1999; New Zealand 2001). However, it was agreed at these summits that a tolerance range of up to 400000 cells $/ \mathrm{mL}$ was necessary for practical reasons (Heeschen 2010). Regardless of the international guidelines, countries still set their own SCC thresholds, indicating that there is still no consensus at the operational level. The reliability of records of clinical mastitis cases depends on accurate detection of mastitis on a day-to-day basis on farms, and these records are often questionable.

The aim of this article is to outline a fresh approach to herd udder health monitoring that facilitates an in-depth analysis of clinical and subclinical mastitis using software that has been developed and tested over the past 15 years at the Faculty of Veterinary Science, University of Pretoria. Currently, more than 930 commercial dairy herds from South Africa and neighbouring countries are benefiting from its application. Sample analysis is paid for by the dairy producers, but it is partially subsidised by the University of Pretoria to keep costs for whole herd analysis reasonable. In return, the University gains current udder health data that can be utilised for pre- and postgraduate student training and research. This data set provides current and historical 
data for research and contains at present results of over 1.6 million milk samples. The Milk Sample Diagnostic (MSD) programme that was developed provides an overview of the current and historical herd udder health situation and allows for analysis related to parity, days in milk and other herd groupings and facilitates decision making on an individual cow level based on current and historic species-specific and udder pathology information. It is used as a practical tool to identify challenges at the herd, cow and udder quarter level and guides decision making at an operational level. Only by addressing the particular cause can the problem be eliminated. This udder health approach differs from the conventional approaches that use primarily SCC and data of clinical mastitis cases as an aid to decision making.

\section{Materials and methods Milk samples and data}

Udder quarter and composite milk samples (one milk sample taken from all four quarters) are taken in most cases from all lactating cows in a herd to establish the presence and prevalence of udder pathogens. Professional milk samplers assist milk producers in South Africa to take samples in an aseptic manner, ensuring that the sample quality is good and that the cold chain is maintained until the samples reach the Milk Laboratory. Most milk samples reach the laboratory within 24 hours. On arrival at the Milk Laboratory (Department of Production Animal Studies, Faculty of Veterinary Science, University of Pretoria, South Africa), the batch temperature of the milk samples is recorded. Milk is then plated out on Bovine Tryptose agar, and cultures are read after 18-24 and $48 \mathrm{~h}$ (Petzer et al. 2012). SCCs were performed using a Fossomatic 5000 (Petzer et al. 2012). Identification of mastitis pathogens is generally completed within $48-72 \mathrm{~h}$ after the samples have been received at the laboratory.

In addition to SCC, culture results, clinical appearance of milk and the general information about the cow are added to the MSD programme. This includes information regarding calving dates, parity, milk yield, stage of pregnancy, status of the udder parenchyma (assessed by palpation) and teat canal scores.

Results of quarter milk and composite milk samples are analysed separately and are summarised in individual cow reports and various group reports.

Some of the various reports that will be discussed:

- The Serial Herd Udder Health Report used for evaluation of composite cow milk samples provides an overview of the current and historical udder health status of the herd based on microbiological and SCC results. The report also provides a perspective on the level of new, persistent and cured cases for each bacterial species isolated from the herds and indicates the SCC distribution within the herd.

- A Current Herd Udder Health Report for analysis of quarter milk samples summarises the SCC and culture results of the current test of the herd as percentage of quarters with mastitis, or with NSD, IMI with low SCC, and the percentage of normal quarters.

- Group Reports focus on species identification, early postpartum reports (for the first 30 days in lactation) and a lactation stage report (5-90, 91-180 and $\geq 180$-day groups) also differentiating between parities.

- The Economic Report provides financial information on probable loss in revenue as a result of milk not being produced because of an udder that is not completely healthy, indicated by the SCC level.

\section{Criteria used for diagnosis}

Microbiology (culture) results and SCCs are available for each quarter milk sample. Many countries set their own operational SCC threshold that is in accordance with recommendations of the World Dairy Summits of less than 400000 cells/mL. An SCC threshold of 300000 was there for chosen for this programme, being midway between the 200000 cells $/ \mathrm{mL}$ recommended by the International Dairy Federation (IDF) and the practical threshold of 400000 cells/mL recommended at the World Dairy Summit. In this programme, quarters that tested bacteria negative with an SCC of below 300000 cells/mL milk were regarded as being normal $(\mathrm{N})$; quarters that tested bacteria positive with an SCC of equal or above 300000 cells/mL milk were regarded as having mastitis $(\mathrm{M})$; quarters that tested bacteria positive with an SCC of below 300000 cells/mL were identified as having a 'teat canal infection' (TCI); and quarters that tested bacteria negative with an SCC of equal or above 300000 cells $/ \mathrm{mL}$ were identified as having an NSD. The desired herd values aimed for are less than 5\% of quarters with mastitis, less than 5\% quarters with TCI, less than 3\% quarters with NSD and more than 50\% normal quarters (Giesecke, Du Preez \& Petzer 1994).

\section{Results and discussions Serial herd health report (composite milk samples)}

The Serial Herd Udder Health Report is presented in two parts. The first part provides a summary overview of one to four consecutive herd examinations based on SCC and culture results of composite milk samples, while the second part deals with the SCC. The current herd udder health status is analysed and compared to results of previous examinations. Positive progress or negative developments in the herd in terms of IMI and SCC trends is measured and evaluated. The various bacterial species isolated from individual cows are indicated as numbers and percentages of cows sampled (see Table 1) while the SCC are summarised according to six threshold levels (Table 2).

\section{Part 1: Serial Herd Microbiological report}

Each bacterial species isolated from individual composite milk samples in the herd is indicated as a number and as a 
TABLE 1: Serial Herd Udder Health Report. Case study Part 1: Bacteriology history report for four consecutive herd examinations of the same herd using composite cow milk samples.

\begin{tabular}{|c|c|c|c|c|c|c|c|c|c|}
\hline \multirow[t]{3}{*}{ Bacteria isolated } & \multirow[t]{3}{*}{ Diagnosis } & \multicolumn{8}{|c|}{ Numbers examined } \\
\hline & & \multicolumn{2}{|c|}{28 October 2014} & \multicolumn{2}{|c|}{17 November 2014} & \multicolumn{2}{|c|}{04 June 2015} & \multicolumn{2}{|c|}{02 July 2015} \\
\hline & & 1290 & $\%$ & 1304 & $\%$ & 1366 & $\%$ & 1297 & $\%$ \\
\hline \multirow[t]{4}{*}{ Staphylococcus aureus } & Total & 78 & 6.05 & 214 & 16.41 & 72 & 5.27 & 58 & 4.47 \\
\hline & New & 78 & 6.05 & 159 & 12.19 & 22 & 1.61 & 12 & 0.93 \\
\hline & Repeat & 0 & 0.00 & 44 & 3.37 & 32 & 2.34 & 27 & 2.08 \\
\hline & Cured & 0 & 0.00 & 11 & 0.84 & 18 & 1.32 & 19 & 1.47 \\
\hline \multirow[t]{4}{*}{ Streptococcus agalactiae } & Total & 24 & 1.86 & 0 & 0.00 & 73 & 5.34 & 45 & 3.47 \\
\hline & New & 24 & 1.86 & 0 & 0.00 & 72 & 5.27 & 40 & 3.08 \\
\hline & Repeat & 0 & 0.00 & 0 & 0.00 & 1 & 0.07 & 5 & 0.39 \\
\hline & Cured & 0 & 0.00 & 1 & 0.80 & 8 & 0.59 & 33 & 2.54 \\
\hline \multirow[t]{4}{*}{ Streptococcus dysgalactiae } & Total & 4 & 0.31 & 0 & 0.00 & 2 & 0.15 & 2 & 0.15 \\
\hline & New & 4 & 0.31 & 0 & 0.00 & 2 & 0.15 & 1 & 0.80 \\
\hline & Repeat & 0 & 0.00 & 0 & 0.00 & 0 & 0.00 & 1 & 0.80 \\
\hline & Cured & 0 & 0.00 & 3 & 0.23 & 1 & 0.70 & 1 & 0.80 \\
\hline
\end{tabular}

TABLE 2: Serial Herd Udder Health Report. Part 2: Somatic cell count history report for four consecutive herd examinations of the same herd based on the results of composite cow milk samples.

\begin{tabular}{|c|c|c|c|c|c|c|c|c|}
\hline \multirow[t]{3}{*}{$\mathrm{SCC} \times 1000$ cells $/ \mathrm{mL}$} & \multicolumn{8}{|c|}{ Dates $\times$ Values ( $\%$ of lactating cows) } \\
\hline & \multicolumn{2}{|c|}{28 October 2014: 1290 cows } & \multicolumn{2}{|c|}{17 November 2014: 1304 cows } & \multicolumn{2}{|c|}{04 June 2015: 1366 cows } & \multicolumn{2}{|c|}{02 July 2015: 1297 cows } \\
\hline & $\%$ & Cum \% & $\%$ & Cum \% & $\%$ & Cum \% & $\%$ & Cum \% \\
\hline $1-125$ & 35.71 & 35.71 & 25.14 & 25.14 & 36.85 & 36.85 & 59.46 & 59.46 \\
\hline $126-250$ & 13.75 & 49.46 & 15.45 & 40.62 & 17.61 & 54.46 & 9.27 & 68.73 \\
\hline $251-375$ & 9.53 & 58.99 & 11.48 & 52.09 & 10.56 & 65.02 & 5.66 & 74.39 \\
\hline $376-500$ & 6.39 & 65.38 & 7.29 & 59.38 & 5.87 & 70.89 & 3.99 & 78.38 \\
\hline $501-750$ & 8.32 & 73.70 & 9.49 & 68.87 & 7.51 & 78.40 & 4.89 & 83.27 \\
\hline$\geq 750$ & 26.30 & 100.00 & 31.15 & 100.00 & 21.60 & 100.00 & 16.73 & 100.00 \\
\hline
\end{tabular}

Cum, Cumulative.

percentage of the total samples examined. Of each bacterial species isolated, the number of new, repeat or persistent cases and cases cured are indicated. In the first examination of a herd, all cases are indicated as new infections. In consecutive herd examinations, new infections are indicated when a specific bacterial species has not been isolated from the same cow at the previous examination; persistent cases are those with identical bacterial isolations as shown previously; and 'cases cured' (those that are culture negative) in the current examination for the specific bacterial species were those that were isolated during the previous examination (Table 1).

\section{Prevalence of species-specific herd intra-mammary infections}

Depending on the principal bacteria present and its prevalence in the herd, management strategies should be planned in collaboration with the herd manager. A policy of zero tolerance is followed in most cases where S. agalactiae and S. aureus are isolated, aiming at the eradication of these bacteria from all udders in these herds. This approach has proved to be practical and successful in South African herds over the past 15 years. The prevalence of $S$. aureus IMI in more than 930 South African commercial dairy herds decreased from 14.08\% in 2008 to 7.77\% in April 2012 (Petzer \& Karzis 2012) and to 5.14\% in December 2014 (Petzer, unpublished data). Bacteriological results as shown in Table 1 provide the veterinarian, udder health consultant and dairy manager and owner with detailed results to assist informed decision making regarding udder health management at the herd level.

\section{New intra-mammary infections}

Depending on the species of bacteria and the level of new IMIs in the herd, deductions can be made regarding parlour hygiene and bedding management (Table 1). Management may prove to be inadequate and protocols may need to be revised and upgraded.

The level of new IMI can be a valuable measurement of effective parlour hygiene and of milker education, dedication and health, especially in the case of contagious mastitis bacteria such as S. aureus and S. agalactiae. It can also indicate ineffective separation of S. aureus- and S. agalactiae-positive cows or an incorrect milking order. The level of new infections may increase if there is a lack of biosecurity when new cows or heifers are introduced into a dairy herd without determining the status of their IMI prior to allowing them on the farm, in the parlour and mixing them with the local herd. Bacteria such as $S$. aureus and Streptococcus pyogenes are known to be able to cause reverse zoonosis (Messenger, Barnes \& Gray 2014). When reverse zoonosis is suspected in a herd, milkers and people in close contact with the cows should be tested for the presence of these bacteria by requesting throat swabs.

When most new IMI are predominantly environmental bacteria such as the coliforms (Escherichia coli, Klebsiella spp. and Serratia spp.) or streptococci other than S. agalactiae, then udder, feet and flank hygiene scores (Cook \& Reinemann 2007) can be performed to quantify the challenge and identify 
areas of risk. Sources may include inadequate management of bedding, which can cause increased levels of loose faeces on bedding surfaces (Reneau et al. 2003), water pollution (mineral or microbial) or overcrowding.

\section{Repeat (persistent) cases and cases cured}

When the same bacterial species is isolated from the same udder (composite milk samples) or the same quarter (quarter milk samples) on two consecutive examinations within a reasonable time period, it is regarded as a repeat or persistent IMI. The percentage of cases that repeat and those cured (bacterial cure) indicate the level of chronicity and the problematic bacterial species or strains present in the herd. It may be an indication of ineffective mastitis treatment. Udders of cows that repeat are palpated to identify possible parenchyma pathology because unsuccessful treatment may be as a result of fibrosis, nodules or atrophy of the udder parenchyma and not necessarily because of bacteria that are resistant to antimicrobials. 'Fibrosis' (hardening udder quarter) is used as an indication of a more recent chronic case compared to 'atrophy' (shrinking udder quarter).

\section{Application of results in a Streptococcus agalactiae- positive herd}

The herd indicated in Table 1 had $3.47 \%$ of cows infected with S. agalactiae at the examination dated 02 July 2015 . Although this percentage decreased from the previous examination on 04 June 2015 (from $5.34 \%$ to $3.47 \%$ ), too many (40 of 45 ) of these infections were new $S$. agalactiae IMI possibly indicating a relaxed parlour hygiene. Five cases of $S$. agalactiae IMI persisted and 33 had been cured since the June examination. The producer was asked to provide information on the whereabouts of 35 cows that were infected with S. agalactiae in June 2015 and which were not tested in July. These cows might have been dried off, removed from the herd or were merely not sampled. The target for new IMI and persistent cases caused by S. agalactiae should both be $<5 \%$. A revised management plan should include better prevention and follow-up of cases that did not cure.

In this case where $S$. agalactiae IMI has been isolated from a herd a partial 'blitz therapy' can be implemented because in this case positive cows have been identified. They should immediately, after conformation of their infections status, be separated from the rest of the cows for the treatment period and until they have been resampled and found to be cured (bacteria free). Retesting of both the lactating herd and treated cows is essential for the successful elimination of S. agalactiae from the herd in a relative short period of time. A percentage of S. agalactiae-infected cows may have been missed during the laboratory examination because of the small volume of milk plated out; or because of sub-minimal concentrations of bacteria present in milk samples; or because of the presence of coagulase-negative staphylococci (CNS) in udders with high SCC initially masking the presence S. agalactiae (personal experience). A short laboratory turnover time in the case of S. agalactiae IMI is crucial to the success of eliminating these bacteria from the herd (Keefe 1997).

\section{Case study: Application of results in a Staphylococcus aureus-positive herd}

In herds where a low prevalence of $S$. aureus is identified, the few positive animals should be culled as soon as possible, and management should focus on sound parlour and milking procedure hygiene. The lactating herd should be retested and quarter udder secretion samples of dry cows in late gestation should be included. When a herd is identified with a medium to high prevalence of $S$. aureus, a longer term strategy is adopted rather than that of culling all positive animals, although culling will form part of the action taken. An important action will be to upgrade the protocol, application of parlour management, the milking routine and the hygiene and monitoring strategies. Other factors such as the within-herd prevalence, the contagiousness of the bacteria, the milk price, the current percentage of cows culled because of mastitis and the number of replacement heifers available must also be considered (Bradley 2007).

The herd indicated in Table 1 was diagnosed with 78 (6.05\%) S. aureus cows in October 2014 and was regarded as herd with a moderate level of infection prevalence. The producer would be advised to separate the $S$. aureus-positive cows, if possible for life, and to keep them in a $S$. aureus group. The results from November 2014 (Table 1) showed an increased in the number of S. aureus cases to $214(16.41 \%)$. Of these, 159 cows $(12.19 \%)$ had new S. aureus infections indicating that the preventative measures were inadequate, 44 cows $(3.37 \%)$ showed persistent infection from the previous test, indicating in these cases a high possibility of chronic cases and only 11 cows $(0.84 \%)$ were apparently 'cured'.

Though the choice and duration of treatment should be discussed with the farmer, the probability of cure could be calculated for each S. aureus-positive cow using the system developed by Sol et al. (1997). This formula incorporates parity (first lactation and higher), stage of lactation (early, mid or late), level of SCC (above or below a linear score of 6.9 or approximately 800000 cells $/ \mathrm{mL}$ ), the number of quarters per udder positive for $S$. aureus (less or more than 3) and quarter position (front or hind) of individual cows, as well as the treatment duration. It can be used to calculate the probability of S. aureus cure (Swinkels et al. 2012) (Figure 1). Information for individual cows on parity, lactation stage, pregnancy status, milk yield, mastitis and SCC history is available in the MSD programme to aid in the decision making. Udders of $S$. aureus cows should be palpated to identify gross parenchyma damage such as fibrosis, nodules and atrophy, which usually would make treatment ineffective. An informed decision could then be made regarding actions to be taken in case of each individual $S$. aureus cow, and a detailed action list for individual cows can be formulated for the manager. This might include intramammary therapy with or without an extended duration, early drying-off with therapy, inactivation of a quarter or culling of the cow. 


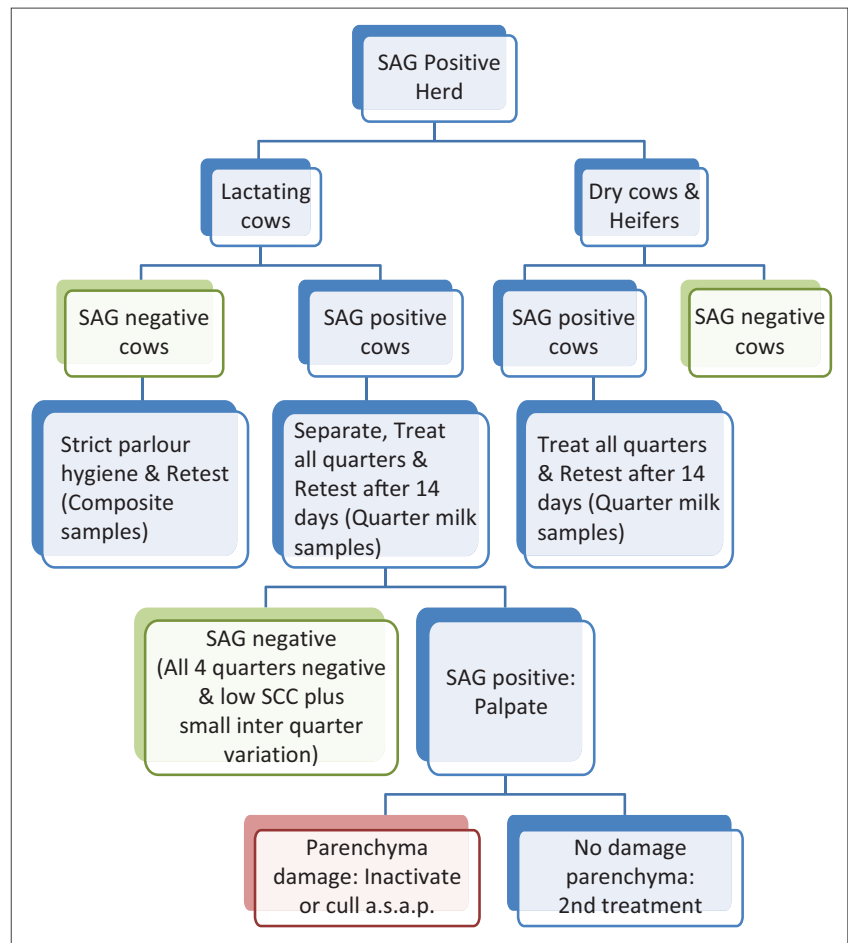

SAG, Streptococcus agalactiae.

FIGURE 1: A flow chart indicating events during the management of a Streptococcus agalactiae intra-mammary infection outbreak in a dairy herd.

In this particular herd (Table 1) at the next examination date on 04 June 2015, the number of new cases had decreased to 22 cows $(1.61 \%)$ of samples, while persistent infections remained relatively low at $32(2.34 \%)$, as does the numbers with bacterial cure (1.32\%). However, Staphylococcus 'cure cases' need to be retested because of the nature of $S$. aureus to shed intermittently. This is the reason why these cows should remain separate from the rest of the herd for life.

South African dairy managers and veterinarians are aware of the existence of reverse zoonosis where infections carried by people may pose a threat to udder health of cows. A noteworthy number of the work force (Statistics South Africa 2013) has immune systems compromised because of HIV with a consequence of an increased risk for disease. Milkers with upper respiratory tract infections caused by $S$. aureus may pose a risk to the udder health of dairy cows if hygienic principles are not adhered to in the parlour (Petzer et al. 2009). Precautions such as the wearing of facial masks and placing milkers that have tested positive for $S$. aureus infections into strategic milking positions where they do not need to touch udders (like teat dipping) have been helpful (personal experience).

\section{Application of results in herds with mainly gram-negative Intra-mammary infection}

When IMI with bacteria of environmental origin is predominant in a herd, the management focus should shift to camps, pasture, bedding and the parlour as sources and areas of risk. The specific bacterial species may provide information on the probable source. Pseudomonas spp. for instance is often found in a water source, and Listeria spp. is mostly present in silage (Hogan \& Smith 2003). In South African pasture-based dairy herds, the prevalence of Streptococcus uberis is increasing (Petzer et al. 2009).

\section{Part 2: Serial herd somatic cell count report}

In the second part of the Serial Herd Udder Health Report, six SCC thresholds are calculated from the herd test (percentages and cumulative percentages). The SCC increments are 125000 cells/mL up to 500000 cells/mL and become larger for higher SCC levels. The herd target is to have more than $80 \%$ of lactating cows with SCC of less than 250000 cells $/ \mathrm{mL}$, while less than $5 \%$ should have an SCC in excess of 750000 cells/mL. Herds with a high percentage (>90\%) of cows with low SCC may be at a higher risk of contracting E. coli mastitis. In such a situation, management practices such as teatdip prior to milking and feeding immediately after milking to prevent cows from lying down would be advised to allow enough time for the teat canal to close. This is especially true of high-yielding herds where the immune system of cows is more likely to be weakened during the first trimester of their lactation (Hogan \& Smith 2003).

SCC dynamics of four consecutive herd investigations from 26 October 2014 to 02 July 2015 are compared in Table 2 . The percentage of cows with SCC below 250000 cells $/ \mathrm{mL}$ is still low in July 2015 (68.13\%), although it has improved from $40.62 \%$ in November 2014. Similarly, the percentage of cows with SCC above 750000 cells / mL decreased from 31.15\% to $16.73 \%$ for the same period but is not yet on target.

In herds with a high proportion of cows with high SCC, a distinction is made between those with and without IMI. In cases where most samples that showed high SCC also had IMI, the sources of these infections should be identified and eliminated or managed. When samples from which no bacteria were isolated form a significant portion of samples with high SCC, possible stressors and causes of udder irritation need to be investigated. Composite milk samples from cows identified with high SCC can be tested on farm with the California Milk Cell test to gain insight into the inter-quarter SCC relation. Heat stress, mud stress, nutritional stress and social or handling stress are examples of stressors that can be responsible for increased SCC (Du Preez 2000). Differences in SCC between quarters of the same udder are used. Physiological changes and stressors to the cow will be more prone to cause an elevated SCC in three or four quarters, while udder irritation is more often seen in only one or two quarters of an udder. The latter can be caused by incorrect milking techniques, incorrect milking machine settings or lack of adequate machine maintenance. Cows that have recently been treated with intra-mammary antimicrobials could also test culture negative with a high SCC.

The probability of incorrect milking machine settings and incorrect use causing irritation can be investigated by using teat canal scoring (Neijenhuis et al. 2001) on first lactating cows, $1-3$ months into lactation. The teat canal is the first line of udder defence and a very important barrier preventing 
IMI when damaged. Pulsator function should be tested by performing the static test on all milking units followed by dynamic testing to check vacuum stability and level at the teat end during milking. Milking machines with high milk lines as well as swing-over parlour systems are still used in South African dairies. Teat canal damage is more likely occur in high-milk lines systems than in low milk lines because when over-milking occurs, the risk of a high-teat-end vacuum is greater in high-line systems that function at a higher system vacuum. Too high-teat-end vacuum is known to be responsible for teat-end damage (Reinemann et al. 2008). Swing-over systems with automatic cluster removers are now installed in South African dairies. Flow metres that measure the milk flow per unit and initiate cluster take-off are installed in these systems far above the level of the udder, and the milk lines transporting milk from the cluster to the flow metres are often more than $1.5 \mathrm{~m}-2.0 \mathrm{~m}$ long. Therefore, it is too long a delay in the time from when the take-off flow rate is reached until the cluster is actually removed, increasing the risk of over-milking.

Milking routine should be monitored on site, and a System Lactocorder (WMB AG, Balgach) can provide measurements of the milk let down time, rate of milk flow and the timing of cluster removal. Automated inline monitoring systems such as Afimilk programme (Afimilk Ltd, Kibbutz Afikim, Israel) are available to identify cows that are in incorrect groups and to identify current and past trends in the milking routine. These can include the time from touch to attachment of clusters, milking speed, cluster fall-off, re-attachment and early detachments. Reasons for insufficient stimulation or delay in take-off can be identified and rectified, whether by training or notifying the milkers or by correcting a milking machine fault.

Nutritional stress can contribute to high SCC and practical methods such as bunker score and space (Bolsen \& Pollard 2004), rumen filling (Burfeind et al. 2010), faecal score and percentage of cows ruminating may be used as a starting point for the investigation in total mixed-ration herds, followed by an in-depth analysis of the feed when indicated.
Cows on pastures and in paddocks may suffer from stress because of mud during the rainy season. In South Africa, the high Temperature Humidity Index (THI) may often have a negative effect on the SCC levels, milk yield and reproduction efficiency during the hot summer months (Du Preez, Giesecke \& Hattingh 1990; Giesecke et al. 1988).

\section{Current herd udder health report (Quarter milk samples)}

A summary of species-specific IMI and SCCs for herds is shown in Table 3. The report is divided into two sections with the first part indicating results from lactating cows and the second part from non-lactating cows. The MSD programme currently uses an SCC level of 300000 cells/mL in quarter milk samples as threshold to diagnose mastitis when IMI is present and NSD in the absence of IMI. Quarters with an SCC level below 300000 cells/mL without IMI are diagnosed as 'normal' and those with IMI as 'TCIs'. Dry cow secretions are only examined for the presence of bacteria and no SCC is done.

Two major concerns can be identified regarding the udder health status in the lactating cows in the herd indicated in Table 3, namely the large percentage of quarters with high SCC and the presence of S. aureus IMI in the herd. Staphylococcus aureus was isolated from $10.6 \%$ of quarters, CNS from $12.4 \%$ and S. uberis and S. agalactiae each from $1.1 \%$. Of the $35.9 \%$ quarters with SCC of 300000 cells $/ \mathrm{mL}$ and above (mastitis and NSD cases), only 6.6\% had IMI, indicating that something besides IMI was prime reason causing high SCC in the herd, even though $25.3 \%$ of all quarters had IMI. More hind than front quarters were diagnosed with NSD and might indicate incorrect removal of clusters.

Of the dry cows sampled 4 weeks after intra-mammary treatment, $12 \%$ were infected with $S$. aureus, $34 \%$ with CNS and $9 \%$ with $S$. uberis. This could indicate a poor cure rate for S. aureus and a possible high new IMI occurring during the dry period for both CNS and S. uberis when compared to the results of the lactating cows (Table 3).

TABLE 3: Current Herd Udder Health Report based on somatic cell count and culture results of quarter milk samples from lactating and dry cows.

\begin{tabular}{|c|c|c|c|c|c|c|c|}
\hline$\overline{\text { Cows }}$ & Diagnosis & Micro-organisms & $\begin{array}{c}\text { Right front } \\
\text { quarters (\%) }\end{array}$ & $\begin{array}{c}\text { Right hind } \\
\text { quarters (\%) }\end{array}$ & $\begin{array}{c}\text { Left front } \\
\text { quarters (\%) }\end{array}$ & $\begin{array}{c}\text { Left hind } \\
\text { quarters (\%) }\end{array}$ & Total (\%) \\
\hline \multirow[t]{8}{*}{ Lactating } & Mastitis & Staphylococcus aureus & 0.0 & 1.1 & 1.1 & 1.1 & 3.3 \\
\hline & Mastitis & CNS & 0.0 & 2.1 & 0.0 & 0.0 & 2.1 \\
\hline & Mastitis & Streptococcus uberis & 0.0 & 0.0 & 0.0 & 1.1 & 1.1 \\
\hline & Normal & None & 14.7 & 10.1 & 9.8 & 10.9 & 45.5 \\
\hline & NSD* & None & 5.9 & 8.4 & 6.4 & 8.6 & 29.3 \\
\hline & $\mathrm{TCI} * *$ & Staphylococcus aureus & 3.3 & 1.8 & 2.2 & 0.0 & 7.3 \\
\hline & $\mathrm{TCl}$ & CNS & 1.1 & 1.5 & 4.4 & 3.3 & 10.3 \\
\hline & $\mathrm{TCl}$ & Streptococcus agalactiae & 0.0 & 0.0 & 1.1 & 0.0 & 1.1 \\
\hline \multirow[t]{4}{*}{ Dry } & Dry Normal & None & 8.0 & 12.0 & 8.0 & 17.0 & 45.0 \\
\hline & Dry IMI & Staphylococcus aureus & 5.0 & 3.0 & 3.0 & 1.0 & 12.0 \\
\hline & Dry IMI & CNS & 10.0 & 8.0 & 11.0 & 5.0 & 34.0 \\
\hline & Dry IMI & Streptococcus uberis & 2.0 & 2.0 & 3.0 & 2.0 & 9.0 \\
\hline
\end{tabular}

Mastitis criteria: SCC $\geq 300000$ cells $/ \mathrm{mL}$ and culture positive; normal criteria: $\mathrm{SCC}<300000$ cells $/ \mathrm{mL}$ and culture negative.

*, NSD: SCC $\geq 300000$ cells $/ \mathrm{mL}$ and culture negative; **, TCI: SCC $<300000$ cells $/ \mathrm{mL}$ and culture positive.

CNS, coagulase-negative staphylococci; NSD, non-specific disturbance or udder irritation; TCI, teat canal infection; IMI, intra-mammary infection; SCC, somatic cell count. 
An action list could be compiled for the producer which may include: S. aureus cows to be followed up by evaluating their mastitis history, performing udder palpation and evaluating criteria of each cow for her probability of cure. The milking machine should be checked, milk routine evaluated and other possible stressors investigated.

\section{Group reports}

Calving dates, pregnancy status, level of milk yield and status of the udder parenchyma can be entered into the MSD programme as information additional to the laboratory results for individual cows.

\section{Pathogen-specific group report}

Reports of cows currently infected with specific udder pathogens are generated to use as on-farm action lists. As explained above, cows should be selected and separated, to deal with contagious IMI such as S. aureus or S. agalactiae IMI in a herd. Cows that have had S. agalactiae IMI and were cured (bacterial cure) may be returned to their previous groups, but $S$. aureus cases should remain in a separate group for life. Reports of consecutive examinations provide information on the dynamics of IMI in the individual cow and identify cows with persistent or chronic IMI.

\section{Application in herds during a Streptococcus agalactiae mastitis outbreak}

During an S. agalactiae IMI outbreak in a dairy herd, composite milk samples are taken from all lactating cows and quarter secretion samples are obtained from the dry cows not currently under antibiotic treatment. When the heifers presently in late gestation had been reared on fresh milk as calves, they are also sampled because of a risk of them having S. agalactiae IMI (Petzer \& Karzis 2012).

The initial list of cows that tested positive for S. agalactiae is emailed to the producer within 24 hours after receiving the samples at the laboratory. Managers should then immediately separate cows that tested positive for S. agalactiae, treat all quarters with of those cows with intra-mammary antimicrobials, and milk these cows last under strict hygiene conditions. Udders of S. agalactiae cows should be palpated to identify gross pathology, in which case the cure rate may be low. Any dry cow or heifers positive for S. agalactiae IMI are also treated.

After 10-14 days after the last intra-mammary treatment, the S. agalactiae-positive cow group is resampled (quarter milk samples) for micro-cytological analysis and composite samples are collected from the rest of the lactating herd. The percentages of $S$. agalactiae cases that are cured, those that persist and the number of new IMI are analysed, and a management plan is formulated based on this information. Cows with $S$. agalactiae IMI are only regarded as being cured when no $S$. agalactiae can be isolated from any of their quarters, when the SCC in all quarters is below 200000 cells $/ \mathrm{mL}$ and when there is only a small variation in the SCC between quarters. The IDF-recommended SCC threshold of 200000 cells $/ \mathrm{mL}$ is used in this case to be extra cautious not to introduce a cow with persistent $S$. agalactiae IMI again into the negative herd. Depending on parlour hygiene and management, it is possible for one S. agalactiaepositive cow to initiate a new outbreak as was experienced in South African herds.

Monitoring of the herd should be continued on a regular basis, and intervals may be monthly or longer until all lactating cows have tested negative for $S$. agalactiae at least two or more consecutive tests. This may take 3-6 months depending on the initial S. agalactiae prevalence as well as the motivation and dedication of the producer and milkers (Figure 1).

For most major udder pathogens, different protocols are required. In the case of a $S$. uberis IMI, different strains were identified (Zadoks 2007). Some strains were found to be more likely to cause chronic IMI while others cured spontaneously after a period of only days. Strain typing of $S$. uberis from individual cow samples on a herd basis has not been shown to be cost effective. When S. uberis is isolated repeatedly from the same cows, the herd manager is advised to increase the duration of intra-mammary treatment only in the event of clinical mastitis in those cows and to use intra-mammary dry cow therapy at drying-off in those specific cows.

\section{Stage of lactation and parity}

The immune system of the lactating cow is known to be weakened during the peripartum period because of hormonal changes and many stressors. These can include calving and onset of lactation stress, social stress and stress because of the adaption to a new diet and the onset of a negative energy balance in the cow that can last up to day 100 of lactation (Collard et al. 2000). Because of vulnerability of the cow during this period, this stage of the production cycle is critical for monitoring udder health.

\section{Udder health up to $\mathbf{3 0}$ days post-partum (multiparous and primiparous cows)}

The number of new IMI and cases with elevated SCC that occur from 5 to 30 days post-partum provides insight into the udder health during the dry period and calving hygiene. It is also an indication of bacterial cure rate during the dry period. However, there is also a risk of new IMI post-partum when milking commences. Knowledge about the prominent bacterial species causing IMI in a herd enables advisors and managers to identify and deal with the sources and causes of infection timeously and effectively. The report that summarises the species-specific IMI information including total, cured, persistent and new IMI for cows between 5 and 30 days can be used to evaluate udder health during the dry period. The current species-specific IMI and SCC results of individual multiparous cows should be compared to their udder health in their previous late lactation. Results for primiparous cows are indicated in a separate report as total numbers (and percentages) of species-specific IMI that have been isolated. Managers should aim to have less than $10 \%$ of 
cows with IMI and SCC in excess of 200000 cells/mL during this period and an incidence of less than $5 \%$ of clinical mastitis (Bradley 2007; Green \& Bradley 2012). An SCC threshold of 200000 cells $/ \mathrm{mL}$ is used to be more strict in management decisions of the post-partum group for they may be more susceptible to new IMI because of calving stress, the onset of lactation, social stress and the possibility of developing a negative energy balance (Barkema et al. 1999; Fenwick et al. 2008).

Heifers are more prone than cows to develop severe udder oedema prior to calving and recently calved primiparous cows are said to have a greater prevalence of mastitis than older cows, despite having less mastitis later in lactation (Barkema et al. 1998). Heifers that are close to calving and primiparous cows should receive a diet with an adequate energy balance and without excessive sodium and potassium (Nestor, Hemken \& Harmon 1988). Stress around calving should be limited by stimulating heifers to exercise and by avoiding overcrowding in order to reduce negative social interactions (Hutjens \& Aalseth 2005). The IMI profile of first lactation cows shortly post-partum is an indication of udder health challenges that have occurred mostly during late pregnancy (environmental bacteria) but can in some cases be traced back to the way they were reared as calves when fed infected milk and kept in groups (Petzer \& Karzis 2012).

When bacteria isolated from milk samples shortly postpartum are predominantly contagious, this may indicate treatment failure, the presence of chronic udder damage or new infections contracted during early lactation. When few cases are cured, treatment protocol needs to be revisited to indicate whether the correct antimicrobial product was used for the correct duration of time.

Udders of treated cows should be palpated to determine if there is chronic udder parenchyma damage (fibrosis, nodules or atrophy). A high rate of new IMI caused by contagious bacteria could be an indication of poor milking hygiene of newly calved cows. Trends of total, cured, new and persistent IMI in a herd can be followed over time to improve management decisions.
In the event where most IMI are caused by environmental bacteria shortly post-partum, causes can be chronic infections or treatment failure but new environmental IMI are more likely to have occurred during the dry period or at calving. Most new IMI caused by environmental bacteria are known to occur just after drying-off and shortly before and after calving (Oliver \& Sordillo 1988). In these situations, daily pre-calving teat dipping during the high-risk periods in the dry period should be added to the management routine. No teat seal is currently registered on the South African market to assist in the prevention of new IMI during the dry period of cows.

\section{Udder Health in early, mid and late lactation (90 days, 180 days and later in lactation)}

Bacteriological and SCC results of milk samples during early, mid and late lactation are compared to evaluate progress or failure of udder health management during lactation (Table 4). Important events occur during the first 90 days of lactation, which includes peak milk production and re-breeding.

Early lactation is also a high-risk period for metabolic diseases and multifactorial stress together with other diseases such as metritis and mastitis (Bell 1995; Pulfer 1991). The status of IMI in cows at calving will determine udder health in that whole lactation. If recently calved cows have a high incidence of IMI, little progress will be made in lowering the BMSCC, as each animal cured during lactation would be replaced by another infected cow that has recently calved. The management aim should be to have less than $15 \%$ cows with SCC in excess of 200000 cells/mL up to 90 days in lactation (Green \& Bradley 2012).

Mid-lactation is generally a lower risk period and a less eventful time for dairy cows than early lactation. During late lactation, the optimum body condition for cows should to be achieved, foetus growth accelerates and cows are prepared for drying-off. The timing of drying-off usually depends on the expected calving date and level of milk yield to allow for a sufficient dry period. Concentrates may need to be reduced when milk yields are still high close to the date of drying-off to prevent excess udder oedema. While there may be a small

TABLE 4: Herd Udder Health status correlated with different stages of lactation using quarter milk samples.

\begin{tabular}{|c|c|c|c|c|}
\hline Diagnosis & Bacteria isolated: Portion of herd & $\begin{array}{c}\% \text { In early lactation } \\
\text { (5-90 days): } 34.78\end{array}$ & $\begin{array}{l}\% \text { In mid-lactation } \\
\text { (91-180 days): } 27.53\end{array}$ & $\begin{array}{l}\% \text { In late lactation } \\
\text { (180+ days): } 37.67\end{array}$ \\
\hline Normal & None & 66.68 & 78.97 & 70.22 \\
\hline Aseptic mastitis (NSD) & None & 14.58 & 6.57 & 12.50 \\
\hline Mastitis & Streptococcus dysgalactiae & 1.04 & 1.31 & 0.00 \\
\hline Mastitis & CNS & 7.30 & 2.62 & 2.87 \\
\hline Mastitis & Streptococcus uberis & 3.13 & 1.31 & 0.96 \\
\hline Mastitis & Staphylococcus aureus & 2.07 & 0.00 & 0.96 \\
\hline Total \% mastitis (M) & - & 13.54 & 5.23 & 4.78 \\
\hline $\mathrm{TCl}$ & CNS & 4.17 & 9.23 & 12.50 \\
\hline $\mathrm{TCl}$ & Streptococcus uberis & 1.04 & 0.00 & 0.00 \\
\hline Total \% (TCI) & - & 5.20 & 9.23 & 12.50 \\
\hline Total \% with IMIs (M + TCI) & - & 18.75 & 14.46 & 17.28 \\
\hline \multicolumn{2}{|c|}{ Total \% with high SCC (M + NSD) - } & 28.12 & 11.81 & 17.28 \\
\hline
\end{tabular}

Mastitis criteria: SCC $\geq 300000$ cells $/ \mathrm{mL}$ and culture positive; NSD criteria: SCC $\geq 300000$ cells $/ \mathrm{mL}$ and culture negative; TCl criteria: $\mathrm{SCC}<300000$ cells $/ \mathrm{mL}$ and culture positive; Normal criteria: $\mathrm{SCC}<300000$ cells $/ \mathrm{mL}$ and culture negative.

NSD, non-specific disturbance; CNS, coagulase-negative staphylococci, TCI, teat canal infection; IMI, intra-mammary infection; SCC, somatic cell count. 
rise in a cow's SCC in late lactation, sharp increases that are seen at this stage may be as a result of udder infection or irritation.

\section{General udder health of the herd}

In the herd used as an example (Table 4 ), $71.38 \%$ of quarters were diagnosed as being normal; $11.6 \%$ with NSD, $7.95 \%$ with mastitis and $9.06 \%$ with TCI. Although the percentage of normal quarters is satisfactory, the $19.55 \%$ of quarter with an SCC above 300000 cells/mL milk is unacceptably high and so are the $17.01 \%$ cases of IMI. The quarters with high SCC in the herd originated from $7.95 \%$ mastitis and $11.6 \%$ NSD cases (Table 4). The main reason for increased SCC is IMI. When no IMI are found in many milk samples with high SCC, the milking machine and stress factors (high THI, overcrowding, mud, nutritional shortcomings and inadequate management) may be indicated as causes (Burvenich et al. 2000; Du Preez et al. 1990; Sandrucci et al. 2014).

The bacteria responsible for IMI in this herd are CNS (13.04\%), S. uberis $(2.14 \%)$, S. aureus $(1.08 \%)$ and Streptococcus dysgalactiae $(0.72 \%)$. It was noted that $72.24 \%$ of IMIs in early lactation were because of mastitic quarters, while only $27.65 \%$ of IMI identified in quarters in late lactation were mastitic (Table 4).

\section{Lactation stages: Intra-mammary infections}

The portion of cows in early (34.78\%), mid (27.53\%) and late lactation (37.67\%) differ in this herd. The percentages of IMI and high SCC quarters were calculated per lactation period (Table 4). There were IMI in $18.75 \%$ of quarters taken from cows in early, $14.46 \%$ in mid and $17.28 \%$ in late lactation (Table 4). The percentage of IMI detected in early lactation cows was high. This would warrant further investigation into the dry period and calving management, persistence of chronic cases, stress during early lactation and suppressed immunity of cows early in lactation. When the IMI increases with days in milk, a distinction should be made between failure to cure of existing IMI (that increased persistent cases) and an increase of new IMI. Persistent cases may be because of udder parenchyma damage, treatment failure or virulent or resistant pathogen strains and a suppressed host immune system. Depending on the bacterial species involved, new infections may originate from the environment (bedding, pastures, water contamination and inadequate milking machine hygiene), the parlour hygiene during the milking routine or when biosecurity is lacking.

\section{Lactation stages: Somatic cell counts}

In the example in Table 4 cows in early lactation had the highest percentage $(28.10 \%)$ quarters with increased SCC compared to mid (11.80\%) and late lactation (17.28\%) cows, although cows less than 5 days in milk (colostrum) are excluded. Quarters identified with mastitis (13.54\%) and NSD (14.58\%) contributed almost equally to the high percentage of SCC found in early lactation (Table 4).
Therefore, in this herd, suspected causes for both IMI and NSD in early lactating cows needed to be investigated.

\section{Economic report}

Estimations are made on the whole herd and do not take into account variations between cows. The MSD programme is used to estimate milk production losses based on quarter milk sample with elevated SCCs (Giesecke et al. 1994; Hortet \& Seegers 1998; Sharma et al. 2011). The herd used as an example in Table 5 had a daily milk production of 2650 litres. The daily milk loss in this herd because of elevated SCC was estimated to be 126.55 litres. This loss represents an estimated loss of 3796 litres per month and 46190 litres annually. This represented an estimated loss of $4.77 \%$ in potential milk production for this herd.

When making a management decision regarding a S. agalactiae IMI in a herd, it is helpful to have an indication of the current production loss because of S. agalactiae. In Table 6, the daily milk production loss in the $S$. agalactiae-infected quarters was estimated to be 37.64 litres amounting to an estimated $1.4 \%$ production loss. Although this case may not warrant blitz therapy to eradicate $S$. agalactiae, the focus should be on improving the milking routine. This calculation is only based on prevalence at the time of sampling and does not incorporate risks of new infection, shedding, cure rate and the number of persistent cases.

\section{Conclusion}

There are many advantages of having species-specific IMI information about udder health in the current MSD system. It allows early detection of IMI, rapid follow-up on information from tests; there is a short turnaround time after the receipting of milk samples and prompt communication of results to herd managers and owners. The programme firstly allows evaluation of the herd udder health situation enabling the consultant to identify the main causes of udder health problems in detail. This will assist in identifying and eliminating the sources of the problems timeously. At the same time, it provides information on each cow on parity, lactation stage, pregnancy status, production level and mastitis and SCC history to enable informed decisions for individual cows and even individual udder quarters. Management decisions can be based on sound information and cows that are cured or have persistent IMI and new IMI can be identified, based on actual bacterial identification. This improves the accuracy of the decisions made. This approach has proved to be practical and to build the confidence of dairy farm managers (personal experience).

\section{Acknowledgements}

We acknowledge Abaci Systems for developing the MSD computer programme, Dr W.H. Giesecke for the original concept of the diagnostic laboratory programme and the milk producers of South Africa for their continuous use and support. Thanks are also due to the staff of the milk laboratory 
TABLE 5: Estimated milk production losses in a herd associated with elevated quarter milk somatic cell counts of all lactating cows in the herd.

\begin{tabular}{|c|c|c|c|c|}
\hline SCC levels $\times 1000$ cells $/ \mathrm{mL}$ & $\begin{array}{l}\text { \% Losses based on the SCC } \\
\text { level of individual quarters }\end{array}$ & Number of quarters per SCC level & Loss in litres & Lost revenue \\
\hline$<125$ & 0.0 & 183 & 0.00 & R 0.00 \\
\hline $125-350$ & 3.7 & 33 & 12.26 & R 54.54 \\
\hline $351-500$ & 11.3 & 14 & 15.88 & R 70.67 \\
\hline $501-750$ & 16.3 & 8 & 13.09 & R 58.25 \\
\hline$>750$ & 25.0 & 34 & 85.32 & R 379.68 \\
\hline Inactive quarters & 100.0 & 0 & 0.00 & $\mathrm{R} 0.00$ \\
\hline
\end{tabular}

Estimated daily milk loss: 126.55 litres values at ZAR 563.14; Estimated monthly milk loss: 3796.43 litres values at ZAR 16894.10; Estimated annual milk loss: 46 190 litres values at ZAR 205544.84. Producer code: 840; Producer: Farmer A; Dairy: Dairy A; Daily milk production: 2650 litres; Milk price per litre: ZAR 4.45; Examination date: 10 September 2015; Selection criteria: All samples tested ( $n=66$ cows).

SCC, somatic cell count.

TABLE 6: Estimated milk production losses in a herd associated with quarters infected with Streptococcus agalactiae.

\begin{tabular}{lccc}
\hline SCC levels $\times \mathbf{1 0 0 0}$ cells/mL. & $\begin{array}{c}\text { \% Losses based on the SCC level of } \\
\text { individual quarters }\end{array}$ & $\begin{array}{c}\text { Number of quarters } \\
\text { per SCC level }\end{array}$ & Loss in litres \\
\hline$<125$ & 0.0 & 1 & 0.00 \\
$125-350$ & 3.7 & 6 & 2.23 \\
$351-500$ & 11.3 & 4 & 4.00 \\
$501-750$ & 16.3 & 2 & 3.54 \\
$>750$ & 25.0 & 11 & 3.27 \\
Inactive quarters & 100.0 & 0 & 27.60 \\
\hline
\end{tabular}

Estimated daily milk loss: 37.64 litres values at ZAR 170.90; Estimated monthly milk loss: 1129 litres values at ZAR 5127.00; Estimated annual milk loss: 13739 litres values at ZAR 62378.50.

Producer code: 840; Producer: Farmer A; Dairy: Dairy A; Daily milk production: 2650 litres; Milk price per litre: ZAR 4.54; Examination date: 18 April 2015 ; Selection criteria: Quarters positive for Streptococcus agalactiae.

SCC, somatic cell count.

of the Department of Production Animal Studies, Faculty of Veterinary Science, Onderstepoort for their continued quality work: Mrs J.C. Watermeyer, F. Konaite, N. Labuschagne, R. Ludike, Miss R. Badenhorst, Mr L.L. Mohapi and K. Malekane for performing the technical work and data logging.

\section{Competing interests}

The authors declare that they have no financial or personal relationships which may have inappropriately influenced them in writing this article.

\section{Authors' contributions}

I-M.P. developed the concept for the MSD computer programme and used and upgraded it, wrote the article and oversaw technical work and data capturing for the manuscript. J.K. assisted with literature search, assisted with the overall structure, verified data and edited the manuscript. E.F.D. assisted with the overall structure, interpretation of data and edited the manuscript. E.C.W. assisted with the overall structure and motivation and edited the manuscript.

\section{References}

Barkema, H.W., Deluyker, H.A., Schukken, Y.H. \& Lam, T.J., 1999, 'Quarter-milk somatic cell count at calving and at the first six milkings after calving', Preventive Veterinary Medicine 38(1), 1-9. http://dx.doi.org/10.1016/S0167-5877(98)00142-1

Barkema, H.W., Schukken, Y.H., Lam, T.J., Beiboer, M.L., Wilmink, H., Benedcitus, G. et al. 1998, 'Incidence of clinical mastitis in dairy herds grouped in three categories by bulk milk somatic cell counts', Journal of Dairy Science 81, 411-419. http:// dx.doi.org/10.3168/jds.S0022-0302(98)75591-2

Barkema, H.W., Schukken, Y.H. \& Zadoks, R.N., 2006, 'Invited review: The role of cow, pathogen and treatment regimen in the therapeutic success of bovine Staphylococcus aureus mastitis', Journal of Dairy Science 89, 1877-1895. http:// dx.doi.org/10.3168/jds.S0022-0302(06)72256-1

Bell, A.W., 1995, 'Regulation of organic nutrient metabolism during transition from late pregnancy to early lactation', Journal of Animal Science 73, 2804-2819.

Bolsen, K.K. \& Pollard, G.V., 2004, 'Feed bunk management to maximize feed intake', Advances in Dairy Technology 16, 227-238.
Bradley, A., 2007, 'Mastitis pattern analysis - A fresh look at the analysis of bovine mastitis: Part 1 - somatic cell count data', United Kingdom Veterinary Journa 12(7), 29-35. http://dx.doi.org/10.1111/j.2044-3870.2007.tb00134.x

Bradley, A.J. \& Green, M.J., 2001, 'Aetiology of clinical mastitis in six Somerset dairy herds', Veterinary Record 148(22), 683-686. http://dx.doi.org/10.1136/ herds', Veterind
vr.148.22.683

Burfeind, O., Von Keyserlingk, M.A.G., Weary, D.M. \& Heuwieser, W., 2010, 'Technical note: Evaluation of a scoring system for rumen fill in dairy cows', Journal of Dairy note: Evaluation of a scoring system for rumen fill in dairy cows', Jou
Science 93(8), 3635-3640. http://dx.doi.org/10.3168/jds.2009-3044

Burvenich, C., Detilleux, J., Paape, M.J. \& Massart-Leen, A.M., 2000, 'Physiology and genetic factors that influence the cow resistance to mastitis, especially during early lactation', Proceeding of the IDF Symposium on Immunology of ruminant mammary gland, 11-14 June 2000, Stresa, Italy, pp. 9-20.

Collard, B.L., Boettcher, P.J., Dekkers, J.C.M., Petitclerc, D. \& Schaeffer, L.R., 2000, 'Relationships between energy balance and health traits of dairy cattle in early lactation', Journal of Dairy Science 83(11), 2683-2690. http://dx.doi.org/10.3168/ jds.S0022-0302(00)75162-9

Cook, N.B. \& Reinemann, D.J., 2007, 'A tool box for assessing cow, udder and teat hygiene', paper presented at the annual meeting of the NMC, 21-24 January 2007, University of Wisconsin, Madison.

Davidson, I., 1961, 'The epidemiology of staphylococcal mastitis', Veterinary Record 73, 1015-1018.

DeGraves, F.J. \& Fetrow, J., 1993, 'Economics of mastitis and mastitis control', Veterinary Clinical Journal of North America: Food Animal Practice 9(3), 421-434. http://dx.doi.org/10.1016/s0749-0720(15)30611-3

Dodd, F.H., Westgarth, D.R., Neave, F.K. \& Kingwill, R.G., 1969, 'Mastitis - The strategy of control', Journal of Dairy Science 52, 689-695. http://dx.doi.org/10.3168/jds. S0022-0302(69)86631-2

Du Preez, J.H., 2000, 'Parameters for the determination and evaluation of heat stress in dairy cattle in South Africa', Onderstepoort Journal of Veterinary Research 67(4), 263-271.

Du Preez, J.H., Giesecke, W.H. \& Hattingh, P.J., 1990, 'Heat stress in dairy cattle and other livestock under southern African conditions. I. Temperature-humidity index mean values during the four main seasons', Onderstepoort Journal of Veterinary Research 57(1), 77-87.

Fenwick, M.A., Llewellyn, S., Fitzpatrick, R., Kenny, D.A., Murphy, J.J., Patton, J. et al., 2008 , 'Negative energy balance in dairy cows is associated with specific changes in IGF-binding protein expression in the oviduct', Reproduction 135(1), 63-75. http://dx.doi.org/10.1530/REP-07-0243

Giesecke, W.H., Du Preez, J.H. \& Petzer, I.M., 1994, Practical mastitis control in dairy herds, Butterworths, Durban. ISBN 978-0-40910-923-8.

Giesecke, W.H., Van Staden, J.J., Barnard, M.L. \& Petzer, I.M., 1988, Major effects of stress on udder health of lactating dairy cows exposed to warm climatic conditions. Technical Communication, No 210, Department of Agricultural and Water Supply, Pretoria, South Africa.

Green, M. \& Bradley, A.J., 2012, Dairy herd health, Lehmanns Media, Berlin, pp. 5-11. ISBN 978-1-84593-997-7.

Halasa, T., Huijps, K., Ǿsterås, O. \& Hoogeveen, H., 2007, 'Economic effects of bovine mastitis and mastitis management: A review', Veterinary Quarterly 29(1), 18-31. $\mathrm{http}: / / \mathrm{dx}$.doi.org/10.1080/01652176.2007.9695224 
Harmon, R.J., 2001, 'Somatic cell counts: A primer', Proceedings of the NMC Annual Meeting, 11-14 February 2001, Madison, Wisconsin, p. 3.

Heeschen, W.H., 2010, 'IDF and mastitis - A general review', Mastitis Research into Practice: 5th IDF Mastitis Conference, proceedings, Christchurch, New Zealand, March 21-24, 2010, pp. 22-32.

Hillerton, J.E., 1999, 'Redefining mastitis based on somatic cell count', Bulletin of the International Dairy Federation 345, 4-6.

Hogeveen, H., Huijps, K., Halasa, T. \& Lam, T.J.G.M., 2010, 'Mastitis costs money: What's new?', Mastitis Research into Practice: 5th IDF Mastitis Conference, Proceedings, Christchurch, New Zealand, March 21-24, 2010, pp. 62-71.

Hogan, J. \& Smith, K.L., 2003, 'Coliform mastitis', Veterinary Research 34, 507-519. http://dx.doi.org/10.1051/vetres:2003022

Hortet, P. \& Seegers, H., 1998, 'Calculate milk production losses associated with elevated somatic cell counts in dairy cows: Review and critical discussion', Veterinary Research 29(6), 497-510.

Hutjens, M.F. \& Aalseth, E.P., 2005, Caring for transition cows, pp. 35-38, viewed 15 September 2015, from https://books.google.com/books?isbn=0932147461

Keefe, G.P., 1997, 'Streptococcus agalactiae mastitis: A review', Canadian Veterinary Journal 38(7), 429-437.

Lactodata Reports, 2014, 17(1), viewed 30 October 2015, from http://www.milksa. co.za/reports/lacto-data-november-2014

Laevens, H., Deluyker, H., Schukken, Y.H., De Meulemeester, L., Vandermeersch, R., De Muêlenaere, $E$ et al., 1997, 'Influence of parity and stage of lactation on the somatic cell count in bacteriologically negative dairy cows', Journal of Dairy somatic cell count in bacterience 80 (12), 3219-3226.
Scient

Lee, C.S., Wooding, F.B.P. \& Kemp, P, 1980, 'Identification properties, and differential counts of cell populations using electron microscopy of dry cow secretions, colostrum and milk from normal cows', Journal of Dairy Science 47, 39. http:// colostrum and milk from normal cows',
dx.doi.org/10.1017/s0022029900020860

Messenger, A.M., Barnes, A.N. \& Gray, G.C., 2014, 'Reverse zoonotic disease transmission (zooanthroponosis): A systematic review of seldom-documented
human biological threats to animals', viewed 12 February 2015, from http:// journals.plos.org/plosone/article?id=10.1371/journal.pone.0089055

Middleton, J.R., 2013, 'Staphylococcus aureus mastitis: Have we learned anything in the last 50 years?' Proceeding NMC Regional Meeting, 23-24 July 2013, Portland Maime.

National Mastitis Council (NMC), 2001, Guidelines on normal and abnormal raw milk based on SCC and signs of clinical mastitis, viewed 15 January 2015, from http:// www.nmconline.org/docs/abnmilk.pdf

Neave, F.K., Dodd, F.H. \& Kingwill, R.G., 1966, 'A method of controlling udder disease', Veterinary Record 78, 521-523. http://dx.doi.org/10.1136/vr.78.15.521

Neave, F.K., Dodd, F.H., Kingwill, R.G. \& Westgarth, D.R., 1969, 'Controlling mastitis in the dairy herd by hygiene and management', Journal of Dairy Science 52 , 696-707. http://dx.doi.org/10.3168/jds.S0022-0302(69)86632-4

Neijenhuis, F., Mein, G.A., Britt, J.S., Reinemann, D.J., Hillerton, H E., Farnsworth, F. et al., 2001, 'Evaluation of bovine teat condition in commercial dairy herds: 4 Relationship between teat-end callosity or hyperkeratosis and mastitis', 2nd Relationship between teat-end callosity or hyperkeratosis and mastitis', 2nd
International Symposium on Mastitis and Milk Quality Proceedings, Vancouver, International Symposium on Mastitis and Milk Qu
BC, Canada, September 13-15, 2001, pp. 362-366.

Nestor, K.E., Hemken, R.W. \& Harmon, R.J., 1988, 'Influence of sodium chloride and potassium bicarbonate on udder edema and selected blood parameters', Journal of Dairy Science 71(2), 366-372. http://dx.doi.org/10.3168/jds.S00220302(88)79565-X

Oliver, S.P. \& Sordillo, L.M., 1988, 'Udder health in the periparturient period', Journa of Dairy Science 71, 2584-2606.

Petzer, I.M. \& Karzis, J., 2012, 'The prevention of intra-mammary infections in pregnant heifers that were co-housed as calves, and reared on whole milk, in eight South African Dairy herds', Livestock Health and Production Annual Congress, proceedings, Stellenbosch, South Africa, April 07-09, 2012, pp. 1-10.

Petzer, I.M., Karzis, J., Meyer, I.A. \& Van der Schans, T.J., 2013, 'A cost-benefit mode comparing the California milk cell test and milk electrical resistance test' Onderstepoort Journal of Veterinary Research 80(1), 6. http://dx.doi.org/10.4102/ ojvr.v80i1.538
Petzer, I.M., Karzis, J., Watermeyer, J.C., Badenhorst, R. \& Van der Schans, T., 2012, 'Trends of Mastitogenic Bacteria from 2008 to 2012 in South African Dairy Herds', IDF World Dairy Summit, Poster Exhibition, Cape Town, South Africa, November IDF Wor, 2012.

Petzer, I.M., Karzis, J., Watermeyer, J.C., Van der Schans, T.J. \& Van Reenen, R., 2009, 'Trends in udder health and emerging mastitogenic pathogens in South African dairy herds', Journal of South African Veterinary Association 80(1), 17-22. http:// dx.doi.org/10.4102/jsava.v80i1.163

Pulfer, K.W., 1991, Treatment of postpartum metritis in dairy cows. lowa State University Veterinarian 53(1), 27-31.

Reinemann, D.J., Bade, R., Zucali, M., Spanu, C. \& Ruegg, P.L., 2008, 'Understanding the influence of machine milking on teat defense mechanisms', Proceedings IDF International Conference on Mastitis Control, 30 September - 02 October 2008, The Hague, The Netherlands.

Reneau, J.K., 2001, 'Somatic cell counts: Measures of farm management and milk quality', Proceedings NMC Annual Meeting, 11-14 February, 2001, Madison, Wisconsin, p. 29.

Reneau, J.K., Seykora, A.J., Heins, B.J., Bey, R.F. \& Farnsworth, R.J., 2003, 'Relationship

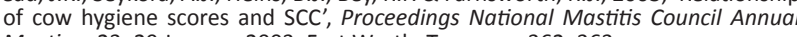
Meeting, 23-29 January 2003, Fort Worth, Texas, pp. 362-363.

Ruegg, P. \& Pantoja, J.F.C., 2013, 'Understanding and using somatic cell counts to improve milk quality', Irish Journal of Agriculture and Food Research 52, 101-117.

Sandrucci, A., Bava, L., Zucali, M. \& Tamburini, A., 2014, Management factors and cow traits influencing milk somatic cell counts and teat hyperkeratosis during different seasons. Revista Brasileira de Zootecnia 43(9), 505-511. http://dx.doi.org/10.1590/ S1516-35982014000900008

Sharma, N., Singhand, N.K. \& Bhadwa, M.S., 2011, 'Relationship of somatic cell count and mastitis: An overview', Asian-Australian Journal of Animal Science 24(3), 429-438. http://dx.doi.org/10.5713/ajas.2011.10233

Shuster, D.E., Lee, E.K. \& Kehrli, M.E. Jr., 1996, 'Bacterial growth, inflammatory cytokine production, and neutrophil recruitment during coliform mastitis in cows within ten days after calving, compared with cows at mid lactation', American Journal of Veterinary Research 57(11), 1569-1575.

Smith, K.L. \& Hogan, J.S., 2001, 'The world of mastitis', 2nd International Symposium on Mastitis and Milk Quality, Proceedings, Vancouver, BC, Canada, September 13-15, 2001, pp. 1-12.

Sol, J., Sampimon, O.C., Snoep, J.J. \& Schukken, Y.H., 1997, 'Factors associated with bacteriological cure during lactation after therapy for subclinical mastitis caused by Staphylococcus aureus', Journal of Dairy Science 80, 2803-2808. http://dx.doi. org/10.3168/jds.S0022-0302(97)76243-X

Statistics South Africa, 2013, P0302, Mid-year population estimates, 14 May 2013, viewed 30 June 2015, from http://www.statssa.gov.za/publications/statsdownload. asp?PPN=p0302\&SCH

Suriyasathaporn, W., Schukken, Y.H., Nielen, M. \& Brand, A., 2000, 'Low somatic cell count: A risk factor for subsequent clinical mastitis in a dairy herd', Journal of Dairy Science 83(6), 1248-1255. http://dx.doi.org/10.3168/jds.S0022-0302(00)74991-5

Swinkels, J.M., Schukken, Y.H. \& Cox, P., 2012, 'Efficacy of short versus long duration of treatment of clinical Staphylococcus aureus mastitis', XXVII World Buiatrics Congress, Proceedings, Lisbon, Portugal, June 3-8, 2012, p. 150.

Wegner, T.N., Schuh, J.D., Nelson, F.E. \& Stott, G.H., 1976, 'Effect of stress on blood leucocyte and milk somatic cell counts in dairy cows', Journal of Dairy Science 59(5), 949-956. http://dx.doi.org/10.3168/jds.S0022-0302(76)84303-2

White, A., 2010, 'Mastitis, a practice approach', Journal of Veterinary Surgeon in General Practice, Livestock 15(7), 36-40. http://dx.doi.org/10.1111/j.2044-3870. 2010.tb00325.x

Yagi, Y., Shiono, H., Chikayama, Y., Ohnuma, A., Nakamura, I. \& Yayou, K., 2004 'Transport stress increases somatic cell counts in milk, and enhances the migration capacity of peripheral blood neutrophils of dairy cows', Journal of Veterinary Medicine 66(4), 381-387. http://dx.doi.org/10.1292/jvms.66.381

Zadoks, R.N., 2007, 'Sources and epidemiology of Streptococcus uberis, with special emphasis on mastitis in dairy cattle', CAB Reviews: Perspectives in Agriculture, Veterinary Science, Nutrition and Natural Resources 2, 15. http://dx.doi. org/10.1079/PAVSNNR20072030

Zeconni, A. \& Smith, K.L., 2000, 'IDF Position paper on ruminant mammary gland immunity', Symposium on Immunology of Ruminant Mammary Gland, 11-14 June 2000, Stresa, Italy, pp. 1-120. 